\title{
Przemówienie Pawta VI do uczestników XI Międzynarodowego Kongresu Federacji „Pueri Cantores”, 10 lipca 1967
}

\section{Jezus powotuje Was do śpiewu}

\section{Drodzy, kochani „Pueri Cantores”!}

Bardzo się cieszymy, że możemy Was przyjąć! Pamiętamy wizytę „Pueri Cantores" z 6 kwietnia 1964, a dzisiaj Wasza obecność na nowo jest dla nas przyjemnością podejmowania Was, słuchania i błogosławienia Wam.

Wiecie, jak doceniamy Wasze stowarzyszenie i jak pragniemy, aby rozszerzało się na cały Kościół - na wszystkie kościoły! - oddając Panu cześć w ceremoniach liturgicznych i różnych nabożeństwach Waszymi dźwięcznymi, kryształowymi i niewinnymi głosami dzieci. Dlatego wszystkich czule witamy, każdemu z osobna i wszystkim razem składamy najlepsze życzenia w Panu, a Waszym Dyrygentom, Asystentom i Nauczycielom śpiewu sakralnego szczerze winszujemy i zachęcamy, by w swej posłudze nie ustali. Zaś jedno słowo, tylko jedna myśl do zapamiętania dla Was, „Pueri Cantores”.

Oto ona: Jezus powołuje Was do śpiewu, do śpiewania dla Niego! Można powiedzieć, że Jezus potrzebuje Waszych głosów i ogromnie się z nich cieszy. Pamiętacie tryumfalny wjazd Jezusa do Jerozolimy, a następnie do świątyni? Lud, a w jego szeregach również dzieci, wyśpiewywał hymny uwielbienia dla Jezusa, rozpoznanego jako Mesjasz, Wysłannik Boga. Podczas gdy nieprzyjaciele Pana chcieli uciszyć owe głosy radości, On, Pan, stanął w obronie tych, którzy Go wychwalali (por. Mt 21, 16; Łk 19, 40). Tak, Jezus powołuje Was do śpiewu, do śpiewania Jemu! Wzywa Was dzisiaj za pośrednictwem Kościoła. Wiecie, że Kościół, podczas Soboru, właśnie tutaj, w tej Bazylice, debatował także na Wasz temat i zarządził, żeby nawet już dzieci w szkołach były kształcone w zakresie śpiewu sakralnego. Właśnie dla Was padło tu nawet szczególnie uprzywilejowane słowo. Rzeczywiście bowiem Konstytucja o liturgii świętej mówi, że zwłaszcza dzieci, imprimis pueri, mają być kształcone liturgicznie w śpiewie sakralnym (por. KL Sacr. Conc. 115). 
Ważne jest, moi Drodzy, bardzo ważne, aby modlitwa Kościoła, modlitwa wspólnoty chrześcijańskiej, ludu wiernego, upiększana była Waszymi głosami, młodszych i starszych dzieci oraz młodzieży. Tak, upiększana, wspierana i czyniona godną wysłuchania w niebie i na ziemi. Pamiętajcie, że macie wielkie zadanie w życiu duchowym Kościoła. Jeśli wyśpiewujecie chwałę na cześć Pana czy inwokacje dla Kościoła, zajmujecie bardzo ważne i bardzo piękne miejsce pośród wszystkich dzieci Kościoła. Mówi Wam to Papież, w imię Jezusa i w Jego imię zachęca Was do dalszej drogi i Wam błogosławi.

\section{„Bliżej ottarza podczas kościelnych liturgii"}

Un mot pour vous, maintenant, chers «petits chanteurs» de langue française, qui êtes, Nous a-t-on dit, les plus nombreux ici ce matin. Un mot, qui voudrait vous dire non seulement qu'il faut chanter, mais pourquoi il faut chanter.

On peut chanter pour bien des raisons: pour se distraire, pour s'égayer; ou pour distraire et égayer les autres; ou encore pour se faire entendre et admirer; on peut chanter, comme vous le faites, pour louer Dieu et rendre plus beau le culte liturgique.

Mais il y a une raison plus belle encore et plus profonde, que Nous allons vous dire en empruntant la voix d'un grand Docteur de l'Eglise, S. Augustin, qui disait: on chante parce qu'on aime - cantare amantis est.

Voilà, chers enfants, pourquoi vous devez chanter, et bien chanter: parce que vous aimez Jésus, et que vous voulez lui faire honneur et lui faire plaisir. Il a fait de vous ses fils, ses frères, ses amis; il vous a associés de plus près que d'autres à la liturgie de son Eglise: montrez lui que vous lui êtes reconnaissants, que vous l'aimez, que vous appréciez ses dons. Et offrez lui, en échange des siens, votre don à vous, votre offrande: celle de votre voix, et de vos efforts pour la cultiver et la rendre toujours plus digne de chanter ses louanges.

Vous vous demandez peut-être, maintenant qu'on chante la messe dans la langue de vos pays, pourquoi on vous fait encore apprendre, en plus, des chants en latin. Mais vous pouvez le comprendre facilement un jour comme celui-ci, où vous êtes rassemblés de tant de nations différentes, et heureux de pouvoir exécuter ensemble les mêmes morceaux dans la langue traditionnelle de l'Eglise latine.

C'est à vous, chers amis, à vos chorales, qu'est confiée, pour une part, la belle mission de conserver dans le peuple chrétien l'usage et l'habitude du chant grégorien, auquel doit s'ajouter maintenant - mais qu'il ne devra jamais remplacer entièrement - l'usage du chant dans vos langues maternelles.

Sachez vous appliquer, avec entrain et bonne humeur, à l'une et l'autre forme du chant, comme le veut l'Eglise et comme vous y exhorte solennellement le récent Concile. 


\section{Dostosować życie do harmonii głosów}

Jedem von euch, liebe junge Sänger, hat Gott eine Stimme geschenkt: klar und schon. Bei der Feier der heiligen Liturgie, bei allen festlichen Darbietungen vereinen sich euere vielen Stimmen zu einem einzigen grossen Jubel zur Ehre Gottes und zur Freude der Menschen.

Euer Singen formt euch zu einer Gemeinschaft junger, froher Menschen, miteinander verbunden in den harten und schwierigen Proben, aber auch in der Freude und Ehre einer erfolgreichen Darbietung. Die hohe Kunst eueres Gesanges verlangt von euch viele Anstrengungen. Ihr müsst auf vieles verzichten, was euer junges Herz erfreuen könnte. Das is aber von grossem Wert für euer ganzes Leben. Es wird euch bewusst, dass euer Singen ein Dienst ist, der Opfer von. euch fordert, der euch aber auch mit der stolzen Freude erfüllen soll, etwas Grosses und Schönes für Gott und euere Mitmenschen tun zu dürfen.

Besides singing all together, you must also sing well. This is not easy; it demands much practice and hard work. But it is possible, and therefore you must practise and work so as to make your singing as perfect as you can.

Your song is your gift to God, and your strive to make that gift as beautiful and attractive as it can possibly be. In this way, your singing will gain your merit in the eyes of God, Who will not fail to reward your efforts, your good will and your search for perfection in His service.

\section{Cudowna wizja z Apokalipsy}

Con vuestra participación en la liturgia de la Iglesia - os diremos ahora en castellano - anticipáis en cierto sentido la liturgia de los bienaventurados en el Paraíso. San Juan en una visión llena de símbolos e imágenes, nos describe la glorificación de Cristo, cordero inmaculado que recibe pleitesía y gratitud en el trono de la gloria, Son primero los representantes de la humanidad redimida los que con cítaras y copas de oro llenas de perfumes entonan un cántico nuevo y le dicen: «Has rescatado para Dios con tu sangre hombres de toda tribu y lengua [...] y has hecho de ellos un rein». Vienen después miriadas de ángeles que corean esta alabanza: «Digno es el cordero que ha sido sacrificado de recibir [...] el honor y la gloria y la bendición». Y finalmente todas las criaturas del cielo, de la tierra y del mar, cantan al unísono: "Al que está sentado en el Trono y al Cordero la bendición, el honor, la gloria y el imperio por todos los siglos» (cf. Apoc., cap. 5).

Amadísimos Hijos: Tomando parte con vuestras voces bonitas en la «laus perennis» de la Iglesia, queréis como recoger el cántico de las criaturas y referirlo a Cristo, por quien todo fue hecho; con vuestros cantos y melodías eleváis al Di- 
vino Esposo la voz dulce de su Esposa la Iglesia; sois como los Angeles en torno a Belén anunciando a la comunidad de sus elegidos la presencia del Redentor; sois gloria de Cristo, sois alegría de la Iglesia.

Tłumaczenie: Kalina Kreczko 